\title{
PERFORMANCE BASED EVALUATION OF MULTISTOREY RC BUILDINGS WITH AND WITHOUT FLOATING COLUMNS BY USER DEFINED HINGES
}

\author{
Suneelakumar Hattarakihal $^{1}$, S.S.Dyavanal ${ }^{2}$ \\ ${ }^{1}$ Post Graduate Student, Department of Civil Engineering, BVBCET, Hubli, Karnataka, India \\ ${ }^{2}$ Professor, Department of Civil Engineering, BVBCET, Hubli, Karnataka, India
}

\begin{abstract}
There is a growing tendency of providing floating column in many multi-storeyed buildings in urban India now a days, due to the lack of availability space for parking, assembly hall and reception lobbies. Building with floating columns is constructed to take advantage of urban bylaws. As per urban bylaws, a pre-specified space should be left open between all sides of the building and the plot boundary. These floating columns are highly undesirable features in building built in earthquake prone areas, because this has been verified in numerous experiences of strong shaking during the past earthquakes like Bhuj 2001. Therefore in the present study the effect of floating columns in multistory RC building is compared with regular building. For the study, four and seven storey symmetric $3 D$ special moments resisting $R C$ frame structure with and without floating columns are considered. The floating columns are provided at cantilever length $1.5 \mathrm{~m}$ along the periphery of the building starting from first floor level up to roof level. ETABS 2013 V13.2 is used for modelling and analysis. The buildings are considered as a fixed based located in seismic zone III on medium soil condition. Linear static such as equivalent static analysis and response spectrum analysis and non-linear static such as pushover analysis are carried out by considering FEMA 440 parameter. Flexural M and PM hinges for beam and column are considered with user defined hinges because user defined hinge represents actual behaviour of members in the structures. The pushover parameters like hinge status, ductility ratio, safety ratio and global stiffness are studied to compare the building with and without floating columns.
\end{abstract}

Keywords: Floating Column, Pushover Analysis, User Defined Hinge, Hinge Status, Ductility And Safety Ratio, Global Stiffness

\section{INTRODUCTION}

The floating columns or hanging columns are the vertical members similar to normal RC columns. The hanging columns are normally constructed above the ground storey, so that the ground storey can be utilized for the parking, play ground, and function halls. These floating columns disturb the uniformity of distribution of loads in the buildings, thus leading to more flexibility and there by weakening the seismic resistance of building shown in figure1.

Building with floating columns is constructed to take advantage of urban bylaws. As per urban bylaws, a prespecified space should be left open between all sides of the building and the plot boundary.

The building with floating columns have both in-plane and out-of-plane irregularities in strength and stiffness and hence are seismically vulnerable. This type of construction does not lead to any problem under the conditions of vertical loading. But during earthquake a clear load path is not available for transferring the lateral forces to the foundation. Lateral forces accumulated in the upper floors during the earthquake have to be transmitted by the projected cantilever beams. Overturning forces thus developed overwhelm the columns of ground floor. Under this situation the columns tend to deform and buckle, resulting in total collapse. Therefore there is a need to understand the seismic behavior of such building and to retrofit the existing buildings with floating columns so that they can withstand further probable earthquake generated forces.

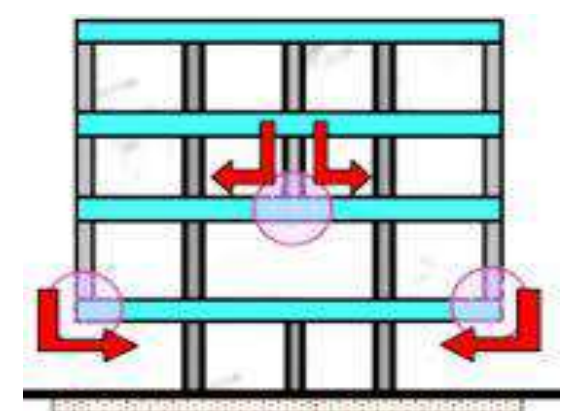

Fig-1: Building with floating column [22]

\subsection{Objective of Study}

The objective of this work is to evaluate through an analytical study, the seismic performance of three dimensional four and seven storey symmetric multistory RC buildings with and without floating columns. Following are the main objectives of the study: 
- To study nonlinear static behaviour of multistorey building with and without floating columns.

- To study the performance parameters like ductility ratio, safety ratio and global stiffness.

\section{METHODOLOGY}

To carry out the performance based evaluation of four and seven storey special moment resisting RC frame structure with and without floating columns located in seismic zone III on medium soil condition, pushover analysis is carried out to compare the basic parameters like hinge status, ductility ratio, safety ratio and global stiffness by using user defined hinges considering FEMA 440 parameters. The buildings are modelled as 3D buildings using ETABS 2013 V13.2. For linear static analysis equivalent static method and response spectrum method as per IS: 1893 (Part 1)-2002 are adopted and for non-linear static analysis pushover method is adopted.

\subsection{Building Considered for the Study}

The plan layouts of the 3D reinforced concrete special moment resisting frame building of four storeyed and seven storeyed building with and without floating columns are shown in Fig 2 and Fig.3, with open ground storey. The base storey height is $4.8 \mathrm{~m}$ and upper storey height is $3.6 \mathrm{~m}$ for all the buildings [24]. The bay dimensions in both directions are kept as $6 \mathrm{~m}$. The building is assumed to be situated in the seismic zone III with medium soil. The building is purposely kept symmetric in both the directions in plan under pure lateral forces. The elevations of the different building models considered are shown in Fig.4 and Fig.5. Beam and column frames are classified as concrete frame elements. Default hinge properties accessible in ETABS according to the FEMA 440 [5] are allotted to the frame elements.

The following models are considered for the study,

Model 1: G+3 and G+ 6 storeys bare frame model without floating column

Model 2: G+3 and G+ 6 storeys bare frame model with floating column.

\subsection{Material Properties}

The basic material properties used for construction are given in Table 4.1 as per IS: 456-2000 [8].

Table-1: Basic material properties of the model [17]

\begin{tabular}{|l|l|}
\hline Material Properties & Values \\
\hline $\begin{array}{l}\text { Characteristic strength of concrete, } \\
\mathrm{F}_{\mathrm{ck}}\end{array}$ & $25 \mathrm{Mpa}$ \\
\hline Yield stress for steel, $\mathrm{F}_{\mathrm{y}}$ & $415 \mathrm{Mpa}$ \\
\hline Modulus of Elasticity of steel, $\mathrm{E}_{\mathrm{s}}$ & $20,0000 \mathrm{Mpa}$ \\
\hline Modulus of Elasticity of concrete, $\mathrm{E}_{\mathrm{c}}$ & $25000 \mathrm{Mpa}$ \\
\hline
\end{tabular}

\subsection{Section Properties}

\begin{tabular}{|c|c|c|}
\hline \multicolumn{2}{|l|}{ Structure } & SMRF \\
\hline \multicolumn{2}{|l|}{ No. of storey } & $\mathrm{G}+3$ and $\mathrm{G}+6$ \\
\hline \multirow{2}{*}{ Storey height } & $\begin{array}{l}\text { Upper } \\
\text { storey }\end{array}$ & $3.6 \mathrm{~m}$ \\
\hline & $\begin{array}{l}\text { Ground } \\
\text { storey }\end{array}$ & $4.8 \mathrm{~m}$ \\
\hline \multicolumn{2}{|c|}{ Type of building use } & Official \\
\hline \multicolumn{2}{|l|}{ Seismic zone } & III \\
\hline \multicolumn{2}{|c|}{ Foundation type } & Isolated \\
\hline \multicolumn{3}{|c|}{ Material Properties } \\
\hline \multicolumn{2}{|c|}{ Grade of Concrete } & $\begin{array}{l}\text { M20 and M30 ( for } \\
\text { cantilever beam) }\end{array}$ \\
\hline \multicolumn{2}{|l|}{ Grade of Steel } & $\mathrm{Fe} 415$ \\
\hline \multicolumn{2}{|c|}{$\begin{array}{l}\text { Young's modulus of M20 } \\
\text { and M30 concrete, E }\end{array}$} & $\begin{array}{l}22.32 \times 10^{6} \mathrm{kN} / \mathrm{m}^{2} \text { and } \\
27.38 \times 10^{6} \mathrm{kN} / \mathrm{m}^{2}\end{array}$ \\
\hline \multicolumn{3}{|c|}{ Member Properties } \\
\hline \multicolumn{2}{|l|}{ Slab thickness } & $125 \mathrm{~mm}$ \\
\hline \multicolumn{2}{|l|}{$\begin{array}{l}\text { Beam size } \\
\text { For Model } 1 \\
\text { For Model } 2\end{array}$} & $\begin{array}{l}300 \mathrm{~m} \times 500 \mathrm{~mm} \\
300 \mathrm{~mm} \times 500 \mathrm{~mm} \\
300 \mathrm{~mm} \times 500 \mathrm{~mm}( \\
\text { overhanging beam, M30) } \\
300 \mathrm{~mm} \times 900 \mathrm{~mm}(1.5 \\
\text { m cantilever beam, M30) }\end{array}$ \\
\hline \multicolumn{2}{|c|}{$\begin{array}{l}\text { Column size } \\
\text { For Model } 1(\mathrm{G}+3 \& \mathrm{G}+6) \\
\text { For Model } 2(\mathrm{G}+3 \& \mathrm{G}+6)\end{array}$} & $\begin{array}{l}500 \mathrm{~mm} \times 500 \mathrm{~mm} \\
500 \mathrm{~mm} \times 500 \mathrm{~mm} \\
\text { interior columns ) } \\
600 \mathrm{~mm} \times 600 \mathrm{~mm} \\
\text { periphery columns }) \\
300 \mathrm{~mm} \times 300 \mathrm{~mm} \text { ( } \\
\text { floating columns ) }\end{array}$ \\
\hline \multicolumn{2}{|c|}{ Thickness of wall } & $300 \mathrm{~mm}$ \\
\hline \multicolumn{2}{|l|}{ Soil type } & Medium soil \\
\hline
\end{tabular}

\subsection{Model Geometry}

The building is analyzed for $\mathrm{G}+3$ and $\mathrm{G}+6$ storeys buildings, for which the number of bays is as specified in Table-1. The geometry details of the models are presented in below Table-2.

Table-2: Geometry of the building [17]

\begin{tabular}{|l|l|l|}
\hline No. of storeys & Four & Seven \\
\hline No. of bays in X-direction & 5 & 5 \\
\hline No. of bays in Y-direction & 5 & 5 \\
\hline Bay width in X-direction & $6 \mathrm{~m}$ & $6 \mathrm{~m}$ \\
\hline Bay width in Y-direction & $6 \mathrm{~m}$ & $6 \mathrm{~m}$ \\
\hline Bottom storey height & $4.8 \mathrm{~m}$ & $4.8 \mathrm{~m}$ \\
\hline Bottom storey height & $3.6 \mathrm{~m}$ & $3.6 \mathrm{~m}$ \\
\hline
\end{tabular}




\subsection{Load Combinations}

The following are the load combinations adopted in the analysis and design of the building, with considerations from IS 1893 (Part 1): 2002 [9].

\begin{tabular}{|l|l|l|}
\hline Sl. No & Method of Analysis & Load combinations \\
\hline 1 & Gravity analysis & 1.5 (DL+LL) \\
\hline 2 & $\begin{array}{l}\text { Equivalent static } \\
\text { analysis }\end{array}$ & $\begin{array}{l}\text { a) } 1.2(\mathrm{DL}+\mathrm{LL}+\mathrm{EQX}) \\
\text { b) } 1.2(\mathrm{DL}+\mathrm{LL}+\mathrm{EQY})\end{array}$ \\
\hline 3 & $\begin{array}{l}\text { Response spectrum } \\
\text { analysis }\end{array}$ & $\begin{array}{l}\text { a) } 1.2(\mathrm{DL}+\mathrm{LL}+\mathrm{RSX}) \\
\text { b) } 1.2(\mathrm{DL}+\mathrm{LL}+\mathrm{RSY})\end{array}$ \\
\hline
\end{tabular}

\subsection{Plan and Elevations of Building Models}

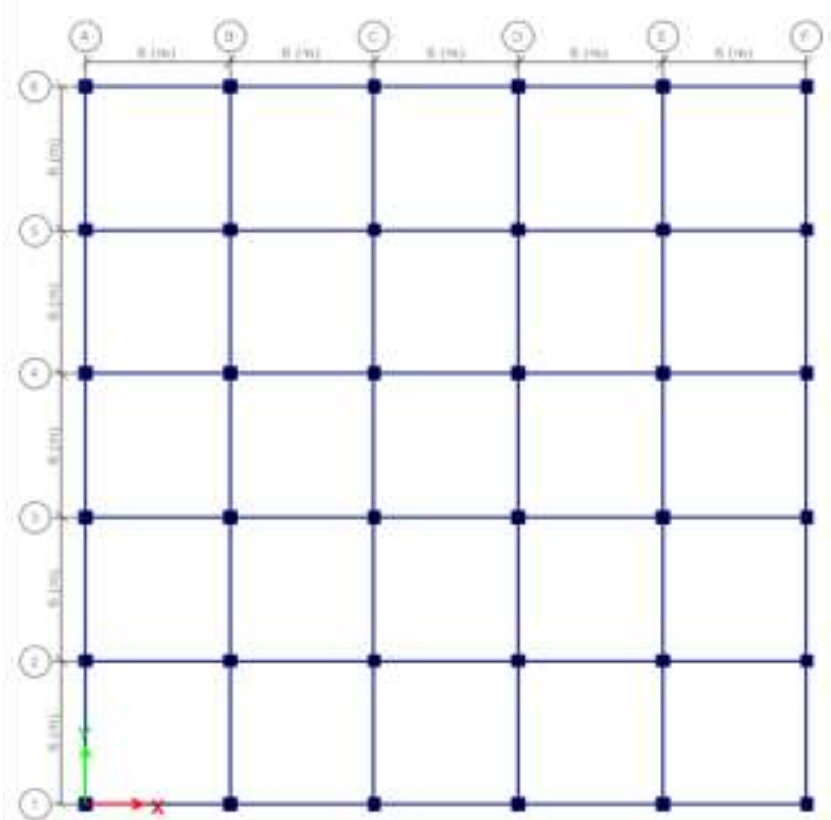

Fig-2: Plan of the building model without floating columns

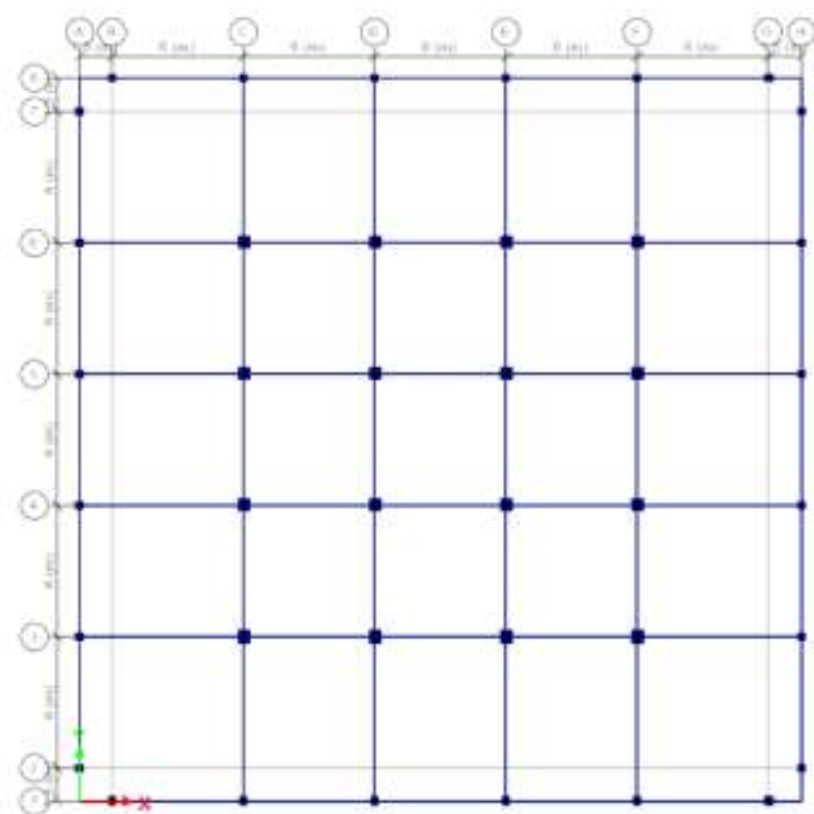

Fig-3: Plan of the building model with floating columns

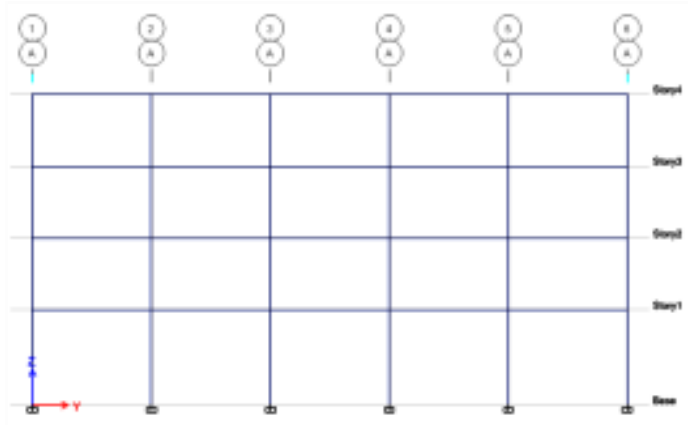

(a)

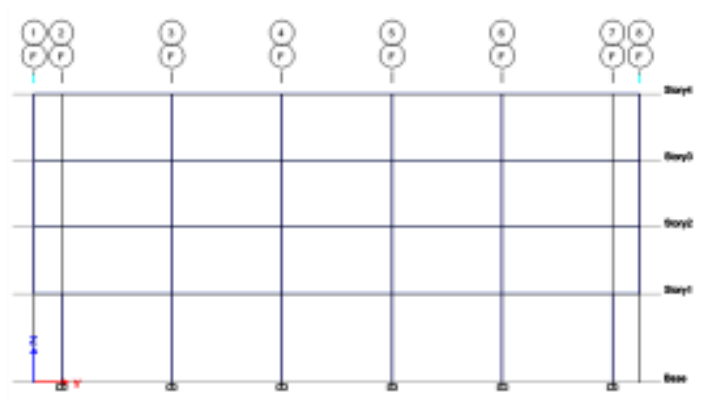

(b)

Fig-4: Elevation of G+ 3 storey Model 1 (a) \& Model 2 (b)

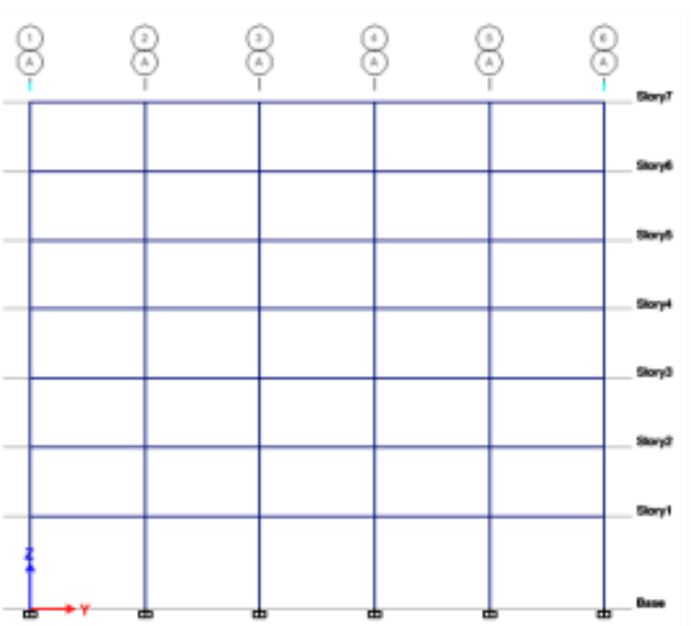

(a)

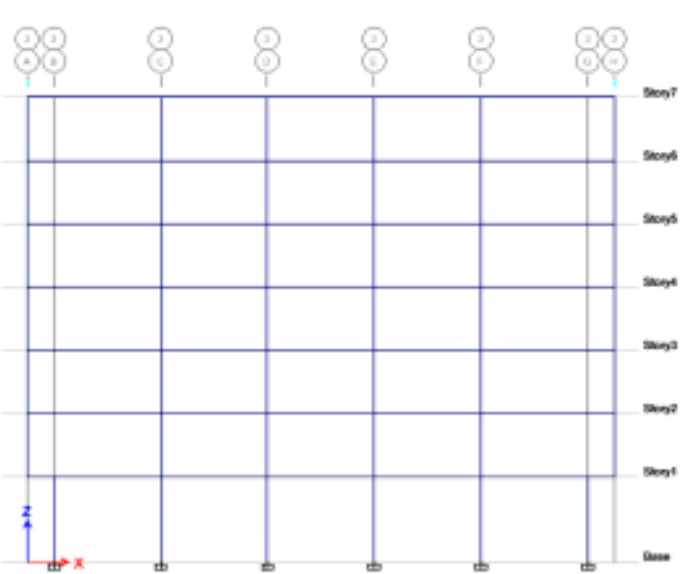

(b)

Fig-5: Elevation of G+ 6 storey Model 1 (a) \& Model 2 (b) 


\section{NON-LINEAR ANALYSIS}

The nonlinear behaviour of the buildings is studied by two methods; namely static and dynamic method. The static method of analysis is most preferred due to its simplicity and reliability. This method is also called as pushover analysis method. This method consists of force controlled and displacement controlled methods.

The present study, considers force controlled procedure for full linear loads and displacement controlled procedure for equivalent static and response spectrum load cases. The performance of the buildings is assessed based on FEMA 440 parameters.

\subsection{User Defined Hinge Properties}

The user defined hinge properties are defined based on moment-curvature analysis of each element. For the present study, the assumption is made such that building deformation occurs due to bending moments, when subjected to lateral seismic loads only. Thus, only M3 hinges were assigned at the two ends of each member. The P-M3 hinges are assigned to columns. The momentcurvature relation for beams and columns is defined manually for a certain group of similar elements. The stressstrain relationship for strut elements is also defined manually.

\subsubsection{Moment Curvature Relation for Beam Section}

The determination of moment-curvature relationship for beam section involves the following procedure. Unconfined concrete model is considered as per IS 456:2000 [8].

- The depth of neutral axis is calculated by equating compressive and tensile forces.

- The maximum depth of neutral axis, $x_{\text {umax }}$, is then determined.

- The $x_{\text {umax }}$ is then divided into equal laminae.

- The strain in fibres is then obtained for each value of $x_{u}$.

- The corresponding Compressive force in fibres is calculated for each depth of neutral axis.

- Then, the moment in the section is calculated by multiplying compressive force ' $\mathrm{C}$ ' with the lever arm ' $Z$ '.

- The curvature is then obtained for each value of $x_{u}$, as a ratio of strain corresponding to that neutral axis depth and the distance from total depth of the section to the level of neutral axis under consideration.

- The moment curvature relation curve is then plotted based on the results obtained.

Table-3: Calculation sheet for Moment-Curvature relation for a concrete beam section [17]

\begin{tabular}{|l|l|l|}
\hline Points & $\begin{array}{l}\text { Moment/ } \\
\text { SF }\end{array}$ & $\begin{array}{l}\text { Curvature/ } \\
\text { SF }\end{array}$ \\
\hline A (Origin) & 0.0000 & 0.0000 \\
\hline B (Yielding) & 1.0000 & 0.0114 \\
\hline C (Ultimate) & 1.7169 & 0.0157 \\
\hline D (strain hardening) & 0.2000 & 0.0157 \\
\hline E (strain hardening) & 0.2000 & 0.1704 \\
\hline
\end{tabular}

\subsubsection{Moment Curvature Relation for Column}

\section{Sections}

The eccentricity of loading affects the design strength of short columns. The design strength of column sections with uniaxial eccentricity of loading is based on two components: a component of axial compression, $\mathrm{P}_{\mathrm{uR}}$, and a corresponding component of uniaxial moment, $\mathrm{M}_{\mathrm{uR}}$, which is a product of $\mathrm{P}_{\mathrm{uR}}$ and eccentricity, e.

The corresponding stresses in the concrete and steel are obtained based on strain developed. The resultant forces are then obtained for both concrete and steel as $\mathrm{C}_{\mathrm{C}}$ and $\mathrm{C}_{\mathrm{s}}$, respectively, by applying static equilibrium condition. The corresponding moments in concrete and steel are then obtained based on axial forces.

There are two prominent cases, which mark the behaviour of columns. The first case is concerned with higher eccentricity, which leads to location of neutral axis within the column section, i.e. $\mathrm{x}_{\mathrm{u}} \leq \mathrm{D}$. The second case considers low eccentricity, leading to location of neutral axis outside the section, i.e. $x_{u}>D$.

The similar procedure as that of beam section is followed and moment and curvature are obtained for various values of neutral axis depths. The PM interaction is obtained, by setting axial load to zero initially and then increasing the axial load until moment reaches zero. It signifies that axial force alone takes care of the deformation capacity of columns, when eccentricities are too high and moment capacity alone serves the purpose when eccentricities are considerably low.

Table-4: P-M interaction and Moment Curvature data for Column section [17]

\begin{tabular}{|l|l|l|}
\hline Points & Moment/SF & Curvature/SF \\
\hline A (Origin) & 0 & 0 \\
\hline B (Yielding) & 1 & 0.00518 \\
\hline C (Ultimate) & 1.006911578 & 0.011666667 \\
\hline D (strain hardening) & 0.2 & 0.011666667 \\
\hline E (strain hardening) & 0.2 & 0.07775 \\
\hline
\end{tabular}

\section{RESULTS AND DISCUSSIONS}

\subsection{Hinge Locations and Performance Evaluation of Building Models}

The pushover analysis is performed by incorporating user defined hinge properties, for both equivalent static (ESM) and response spectrum (RSM) load cases. The target displacement is set to $4 \%$ of the building height. The results of hinge location at various performance levels are presented in the table- 5 to table- 8 . 
Table-5: Location of hinges for four storey building models (ESM)

\begin{tabular}{|c|c|c|c|c|c|c|c|c|c|c|}
\hline \multirow{2}{*}{$\begin{array}{l}\text { Mod } \\
\text { el } \\
\text { No. }\end{array}$} & \multirow{2}{*}{\multicolumn{2}{|c|}{ Displacement (mm) }} & \multirow{3}{*}{$\begin{array}{l}\begin{array}{l}\text { Base } \\
\text { Force } \\
(\mathbf{k N})\end{array} \\
7766.15\end{array}$} & \multicolumn{7}{|c|}{ Hinge Locations } \\
\hline & & & & \multirow{2}{*}{$\begin{array}{l}\mathbf{A}-\mathbf{B} \\
528\end{array}$} & \multirow{2}{*}{$\begin{array}{l}\text { B-IO } \\
98\end{array}$} & \multirow{2}{*}{$\begin{array}{l}\text { IO-LS } \\
142\end{array}$} & \multirow{2}{*}{$\begin{array}{l}\text { LS- } \\
\text { CP }\end{array}$} & \multirow{2}{*}{$\begin{array}{l}\text { CP- } \\
\text { C } \\
0\end{array}$} & \multirow{2}{*}{$\begin{array}{l}\text { C-D } \\
0\end{array}$} & \multirow{2}{*}{$\begin{array}{l}\text { Tota } \\
768\end{array}$} \\
\hline \multirow{2}{*}{1} & Yield & 56.6 & & & & & & & & \\
\hline & Ultimate & 256.92 & 8179.43 & 528 & 0 & 238 & 2 & 0 & 0 & 768 \\
\hline \multirow{2}{*}{2} & Yield & 68 & 3588.62 & 716 & 228 & 0 & 0 & 0 & 0 & 944 \\
\hline & Ultimate & 307.9 & 5942.27 & 475 & 241 & 134 & 44 & 0 & 50 & 944 \\
\hline
\end{tabular}

Table-6: Location of hinges for four storey building models (RSM)

\begin{tabular}{|c|c|c|c|c|c|c|c|c|c|c|}
\hline \multirow{2}{*}{$\begin{array}{l}\text { Mod } \\
\text { el } \\
\text { No. }\end{array}$} & \multirow{2}{*}{\multicolumn{2}{|c|}{ Displacement (mm) }} & \multirow{3}{*}{$\begin{array}{l}\text { Base Force }(\mathbf{k N}) \\
8429.7 \\
\end{array}$} & \multicolumn{7}{|c|}{ Hinge Locations } \\
\hline & & & & \multirow{2}{*}{$\begin{array}{l}\text { A-B } \\
474 \\
\end{array}$} & \multirow{2}{*}{$\begin{array}{l}\text { B-IO } \\
294 \\
\end{array}$} & \multirow{2}{*}{$\begin{array}{l}\text { IO-LS } \\
0\end{array}$} & \multirow{2}{*}{$\begin{array}{l}\text { LS- } \\
\text { CP } \\
0\end{array}$} & \multirow{2}{*}{$\begin{array}{l}\text { CP- } \\
\text { C } \\
0\end{array}$} & \multirow{2}{*}{$\begin{array}{l}\text { C-D } \\
0\end{array}$} & \multirow{2}{*}{$\begin{array}{l}\text { Total } \\
768\end{array}$} \\
\hline & Yield & 64.6 & & & & & & & & \\
\hline 1 & Ultimate & 276.98 & 11615.84 & 420 & 120 & 122 & 50 & 0 & 56 & 768 \\
\hline \multirow{2}{*}{2} & Yield & 77.5 & 3985.27 & 784 & 160 & 0 & 0 & 0 & 0 & 944 \\
\hline & Ultimate & 311.4 & 6937.94 & 538 & 251 & 87 & 20 & 0 & 48 & 944 \\
\hline
\end{tabular}

Table-7: Location of hinges for seven storey building models (ESM)

\begin{tabular}{|c|c|c|c|c|c|c|c|c|c|c|}
\hline \multirow{2}{*}{$\begin{array}{l}\text { Mod } \\
\text { el } \\
\text { No. }\end{array}$} & \multirow{2}{*}{\multicolumn{2}{|c|}{ Displacement (mm) }} & \multirow{2}{*}{$\begin{array}{l}\text { Base } \\
\text { Force } \\
(\mathbf{k N})\end{array}$} & \multicolumn{7}{|c|}{ Hinge Locations } \\
\hline & & & & \multirow{2}{*}{$\begin{array}{l}\text { A-B } \\
846\end{array}$} & \multirow{2}{*}{$\frac{\text { B-IO }}{238}$} & \multirow{2}{*}{$\begin{array}{l}\text { IO-LS } \\
260\end{array}$} & \multirow{2}{*}{$\begin{array}{l}\text { LS- } \\
\text { CP } \\
0\end{array}$} & \multirow{2}{*}{$\begin{array}{l}\text { CP- } \\
\text { C } \\
0\end{array}$} & \multirow{2}{*}{$\begin{array}{l}\text { C-D } \\
0\end{array}$} & \multirow{2}{*}{$\begin{array}{l}\text { Total } \\
1344\end{array}$} \\
\hline 1 & Yield & 78.65 & 7194.11 & & & & & & & \\
\hline 1 & Ultimate & 369.2 & 7585.39 & 850 & 192 & 230 & 16 & 0 & 56 & 1344 \\
\hline \multirow{2}{*}{2} & Yield & 108.3 & 3077.66 & 1456 & 328 & 0 & 0 & 0 & 0 & 1784 \\
\hline & Ultimate & 435.54 & 5608.1 & 887 & 546 & 253 & 25 & 2 & 71 & 1784 \\
\hline
\end{tabular}

Table-8: Location of hinges for seven storey building models (RSM)

\begin{tabular}{|c|c|c|c|c|c|c|c|c|c|c|}
\hline \multirow{2}{*}{$\begin{array}{l}\text { Mod } \\
\text { el } \\
\text { No. } \\
\end{array}$} & \multirow{2}{*}{\multicolumn{2}{|c|}{ Displacement (mm) }} & \multirow{3}{*}{ 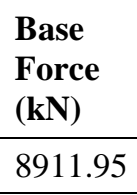 } & \multicolumn{7}{|c|}{ Hinge Locations } \\
\hline & & & & \multirow{2}{*}{$\begin{array}{l}\text { A-B } \\
856\end{array}$} & \multirow{2}{*}{$\begin{array}{l}\text { B-IO } \\
332 \\
\end{array}$} & \multirow{2}{*}{$\begin{array}{l}\begin{array}{l}\text { IO- } \\
\text { LS }\end{array} \\
156\end{array}$} & \multirow{2}{*}{$\begin{array}{l}\text { LS- } \\
\text { CP } \\
0 \\
\end{array}$} & \multirow{2}{*}{$\begin{array}{l}\text { CP- } \\
\text { C } \\
0\end{array}$} & \multirow{2}{*}{$\begin{array}{l}\text { C-D } \\
0\end{array}$} & \multirow{2}{*}{$\begin{array}{l}\text { Total } \\
1344\end{array}$} \\
\hline \multirow{2}{*}{1} & Yield & 60.79 & & & & & & & & \\
\hline & Ultimate & 250.64 & 9948 & 848 & 304 & 120 & 18 & 0 & 54 & 1344 \\
\hline \multirow{2}{*}{2} & Yield & 90 & 3535.93 & 1538 & 246 & 0 & 0 & 0 & 0 & 1784 \\
\hline & Ultimate & 360.86 & 6645.9 & 1109 & 434 & 129 & 40 & 0 & 72 & 1784 \\
\hline
\end{tabular}

The hinge formation status for four and seven storeys building models with and without floating columns is presented in Table-5 to Table- 8 . It is observed that, at the performance point the base force of building models without floating columns is higher than the building models with floating columns. For four storey building models, the base force is found more in building model without floating columns compared to building model with floating columns by $37.64 \%$ and $67.42 \%$ at the ultimate state by equivalent static and response spectrum analysis, respectively. For seven storey building, the model without floating columns resulted in higher base force than model with floating columns by $35.25 \%$ and $49.68 \%$ at ultimate state by equivalent static and response spectrum analysis, respectively.
In four storey bare frame building models, hinges formed within the life safety range at the ultimate state are $99.73 \%$ and $90.09 \%$ for models without floating columns and with floating columns, respectively. It is also observed that the hinges formed beyond the $\mathrm{CP}$ range at the ultimate state are $0.26 \%$ and $9.95 \%$, for models without floating columns and with floating columns respectively.

In seven storeys bare frame building models, hinges formed within the life safety range at the ultimate state are $94.64 \%$ and $94.50 \%$, for models without floating columns, with floating columns, respectively. It is also observed that, the hinges formed beyond the $\mathrm{CP}$ range at the ultimate state are $5.35 \%$ and $5.49 \%$ models without floating columns and with floating columns, respectively. 


\subsection{Ductility Ratio}

Ductility ratio is defined as the ratio of collapsed yield to the initial yield [17]. The lateral stiffness of the building increases the lateral strength, but reduces the energy absorption capacity of the building, hence ductility ratio decreases. In this study, the ductility parameters of all the building models are studied by performing pushover analysis for equivalent static and response spectrum load cases. The Fig- 6 and Fig-7 present the ductility ratios of all the models.

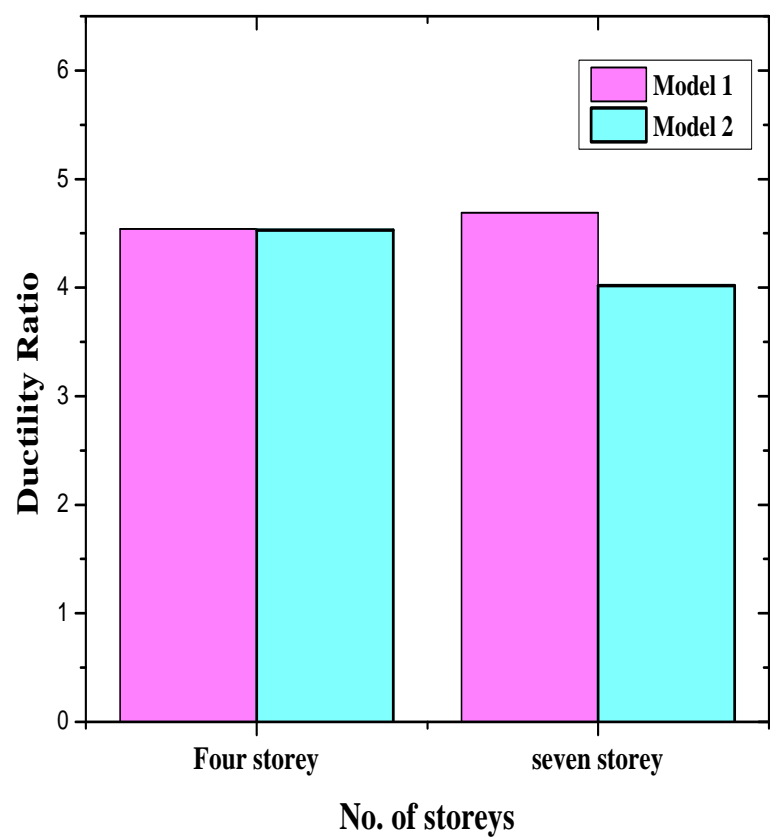

Fig-6: Ductility ratio of building models by equivalent static pushover analysis

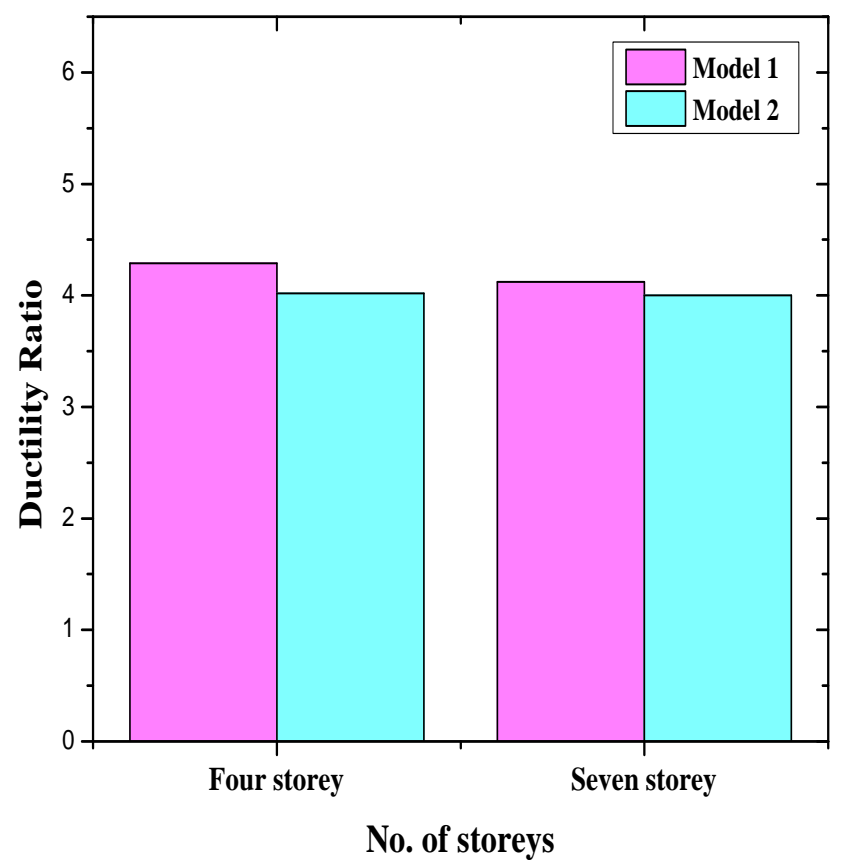

Fig-7: Ductility ratio of building models by response spectrum pushover analysis
From above result it is clear that the ductility ratio of the model 1 is larger than that of the models 2 . It is seen from Fig-6 and Fig-7 that the ductility ratio of model 1 and model 2 in four and seven storeys are less than the reduction factor equal to 5 .

\subsection{Safety Ratio}

Safety ratio is defined as the ratio of base force obtained at performance point to the base shear obtained by equivalent static method. If the safety ratio is equal to one then the structure is called safe, if it is less than one than the structure is unsafe and if ratio is more than one then the structure is over safe [24]. The safety ratio obtained for the models under consideration is presented in Fig-8 and Fig-9.

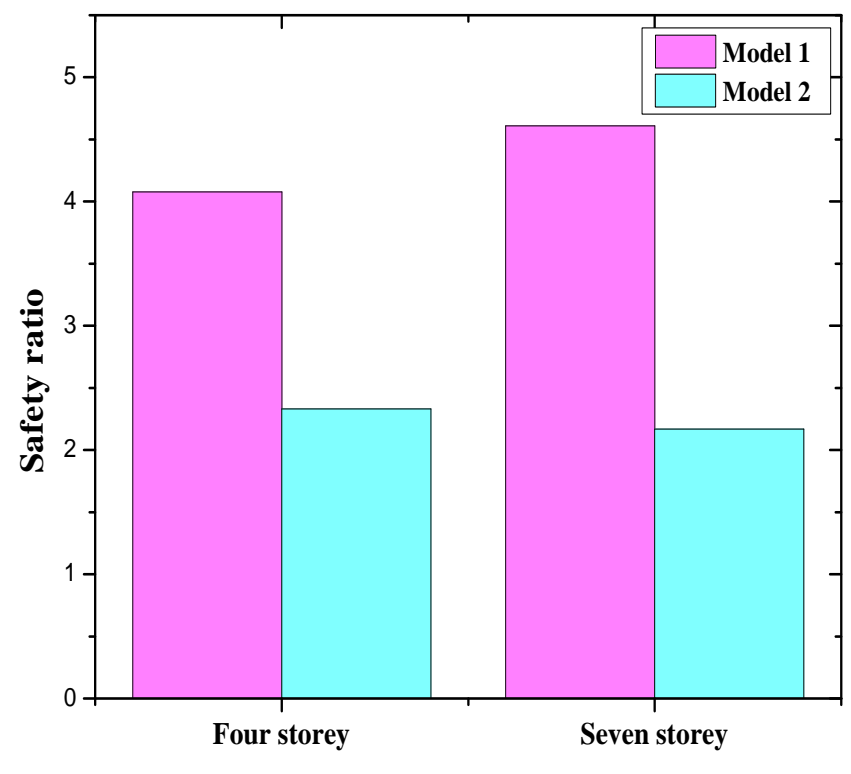

No. of storeys

Fig-8: Safety ratio of building models by equivalent static pushover analysis

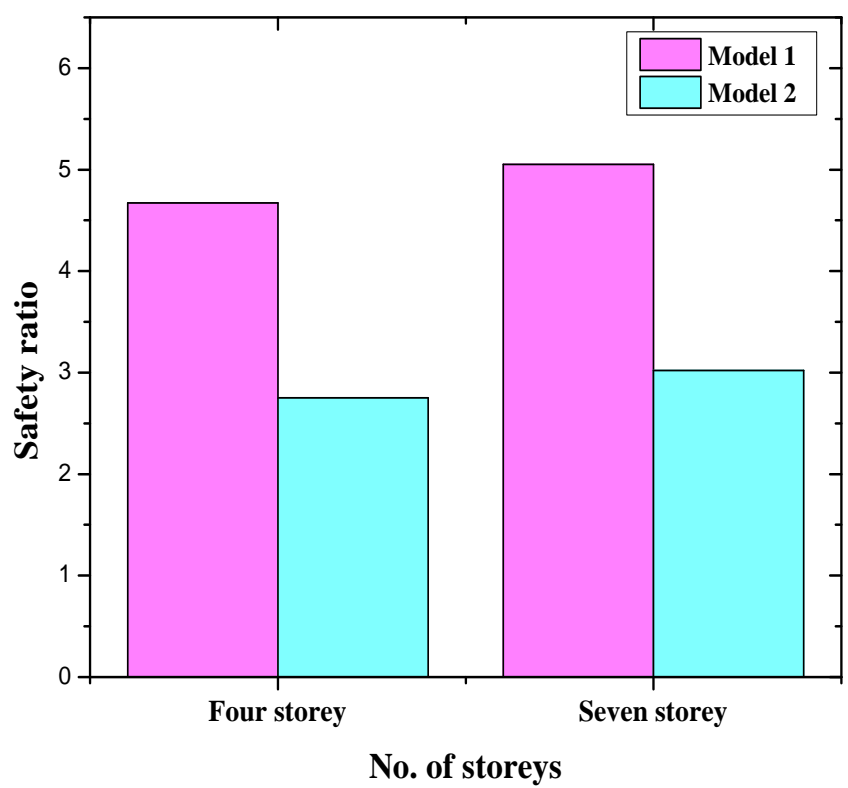

Fig-9: Safety ratio of building models by response spectrum pushover analysis 
It is seen from Fig-8 and Fig-9 that the four storey building model without floating columns is found to be 1.75 times safer than the models with floating column. In seven storey building models, for bare frame models without floating columns is found to be 2.12 times safer than the models with floating columns by equivalent static pushover analysis. Similarly in four and seven storey model without floating columns is found to be 1.69 and 1.67 times safer than the models with floating columns, respectively, by response spectrum pushover analysis.

\subsection{Global Stiffness}

Global stiffness is defined as the ratio of performance base shear to the performance displacement [19]. The global stiffness is shown in Fig-10 and Fi9-11.

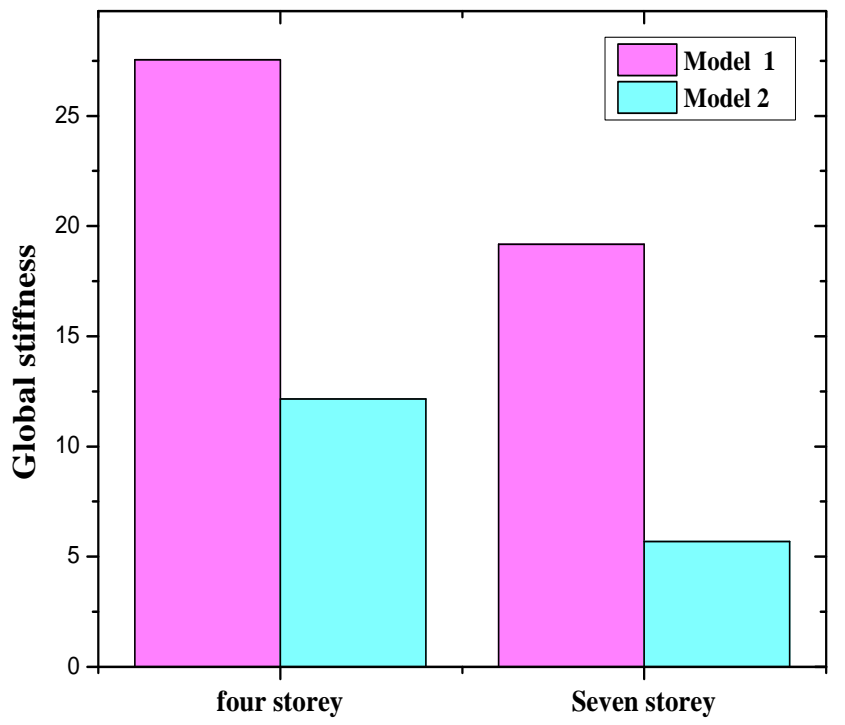

No. of storeys

Fig-10: Global stiffness of building models by equivalent static pushover analysis

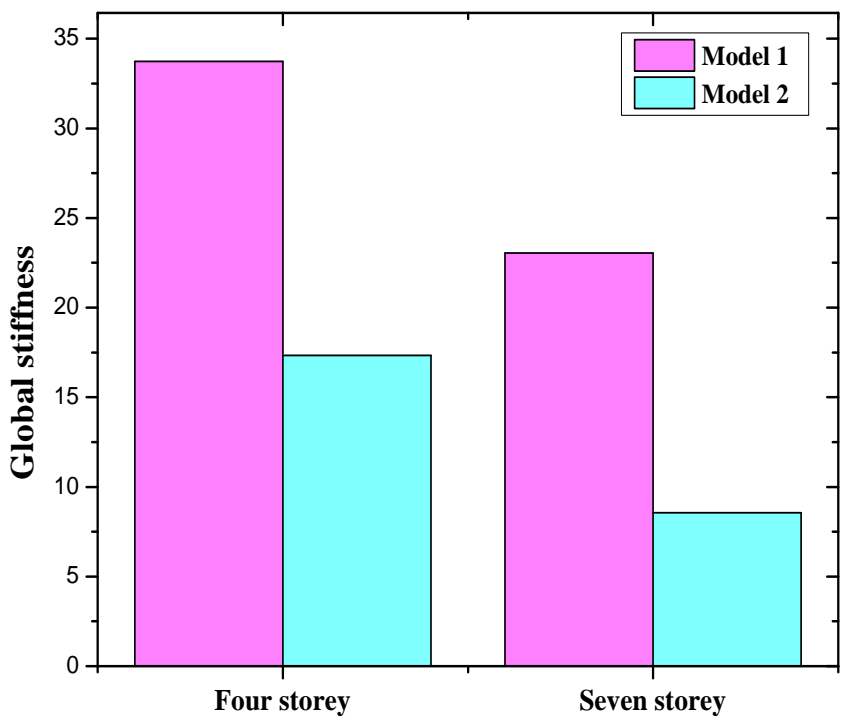

No. of storeys

Fig-11: Global stiffness of building models by response spectrum pushover analysis
It can be observed that, the stiffness of the building models without floating columns is higher than the building models with floating columns. For four storey building models, there is an increment in the percentage of global stiffness of bare frame models without floating columns compared to models with floating columns by $126.74 \%$ and for seven storey building models, the increment in the percentage of global stiffness of bare frame models without floating columns is $236.90 \%$ than the models with floating columns by equivalent static pushover analysis. Similarly for four and seven storey models, the increment in percentage of global stiffness for model without floating columns by $94.57 \%$ and $169.27 \%$ compared to models with floating columns, respectively, by response spectrum pushover analysis.

\section{CONCLUSION}

1. The performance level of all the models is found within the life safety range and the number of plastic hinges in life safety level at performance point is more than the collapse prevention level at the ultimate state for pushover analysis with both equivalent static and response spectrum load cases.

2. The displacement at performance point of buildings with floating columns is more compared to regular building.

3. The base force at performance point of buildings with floating columns is less compared to building models without floating columns.

4. Ductility ratios of four and seven storey building models with and without floating columns are in the range of 4 to 6 . Thus ductility demand is less than their ductility capacity by both equivalent static and response spectrum pushover analysis.

5. Safety ratios of all the models are more than one. This reveals that all the models are safe.

6. Global stiffness of the floating column building is found to be very less when compared to the regular building so it is better to avoid floating columns in earthquake prone areas.

\section{REFERENCES}

[1] Agarwal, P.and Shrikhande, M. (2006), "Earthquake design of structures" Prentice Hall of India Private Limited New Delhi India.

[2] Applied Technology Council (1996), "Seismic Evaluation and Retrofit of Concrete Buildings", Vol.1\& 2, California.

[3] Federal Emergency Management Agency, FEMA-273 (2000), "NEHRP Guidelines for the Seismic Rehabilation of Buildings. Washington D.C.

[4] Federal Emergency Management Agency, FEMA-356 (2000), "Pre Standard and Commentary for Seismic Rehabilitation of Buildings". Washington (DC).

[5] Federal Emergency Management Agency, FEMA-440 (2005), "Improvement of Nonlinear Seismic Analysis Procedures". California.

[6] Hardik, B. and Siddharth, S. (2015), "Pushover Analysis of RC Frame Structure With Floating Column 
and Soft Story in Different Earthquake Zones", International Journal of Research in Engineering and Technology, Vol.4, Apr, Issue: 04.

[7] Habibullah, A. and Pyle, S. (1998), "Practical three dimensional nonlinear static pushover analysis", Structure Magazine

[8] IS 456:2000, "Code of Practice for Plain and Reinforced Concrete", Bureau of Indian Standards, New Delhi, India.

[9] IS 1893 (Part 1):2002, "Criteria for Earthquake Resistant Design of Structures", Bureau of Indian Standards, New Delhi 110002.

[10] IS 13920:1993, "Code of Practice for Plain and Reinforced Concrete", Bureau of Indian Standards, New Delhi, India.

[11] Kavya, N., Manjunatha, k. and Sachin, P.D. (2015), "Seismic evaluation of multistorey RC building with and without floating column", International Research Journal of Engineering and Technology, Volume: 02, Sep, Issue: 06.

[12] Krutarth, S. P., Sumant,B. P. and Snehal, V.M. (2016), "Effect of various positions of floating columns on a building with and without provision of infill walls", International Journal of Advance Research in Engineering, Science \& Technology, Volume 3, Apr, Issue 4.

[13] Park, R. and Paulay, T. (1975), "Reinforced Concrete Structures," Christ church, New Zealand, Aug, pp. 270343, 1974.

[14] Prashanta, B.G. and Dyavanal, S.S. (2007), "Performance Based Seismic Evaluation of Multistoreyed Buildings with the Openings in U M Infill Walls", RDSE-2007, Manipal Institute of Technology, Manipal. 30-31 ${ }^{\text {st }}$ August.

[15] Praveen, R. and Dyavanal, S.S. (2014), “ Non-linear static analysis of $\mathrm{G}+6$ storeyed $\mathrm{RC}$ building with openings in infill walls", International Journal of Engineering Research and Applications, Volume 4, Sep, Issue 9.

[16] Rama, R.K., Cinitha, A. and Nagesh, R.I. (2012), "Seismic Performance Evaluation of Existing RC Buildings Designed as per Codes of Practice", Sadhana Vol. 37, Part 2, April 2012, pp. 281-297. Indian Academy of Sciences, CSIR-Structural Engineering Research Centre, CSIR Campus, Taramani, Chennai 600 113, India.

[17] Rihan, M. "Seismic Evaluation of Multistorey Buildings with Soft Storey", M.Tech Thesis - 2013.

[18] Sabari, S. and Praveen, J.V. (2015), "Seismic Analysis of Multistorey Building with Floating Column", International Journal of Civil and Structural Engineering Research, Vol. 2, Mar, Issue 2, pp: (1223).

[19] Sarita, S. and Ashfi, R. (2015), "Effect of Floating Columns on Seismic Response of Multi-Storeyed RC Framed Buildings", International Journal of Engineering Research \& Technology (IJERT), Vol. 4, Jun, Issue 06.

[20] Shuraim, A. and Charif, A. (2007), "Performance of pushover procedure in evaluating the seismic adequacy of reinforced concrete frames", Proceedings of the 7th Saudi Engineering Conference (SEC7).

[21] Srikanth, M.K. and Yogeendra, R.H. (2014), "Seismic Response of Complex Buildings with Floating Column for Zone II and Zone V", International journal of Engineering Research, Vol. 2.

[22] Stella, E., Satish, D. and Raghava Rao, E.V. (2015), "Push over Analysis for RC Building With and Without Floating Columns", International Journal of Advancements in Research \& Technology, Volume 4, November, Issue 11.

[23] Suchita, H. and Dhananjay, R. (2016), "Seismic Performance of Multi-Storey RCC Building with Floating Columns", International Journal of Engineering Research, Volume No.5, Feb, Issue: Special 3, pp: 777-785, 27-28.

[24] Veeresh, B.K. "Seismic Evaluation and Retrofitting of Soft Ground RC Multistorey Buildings" M.Tech Thesis (2006). 